\title{
Para Cuma
}

\author{
How Black Friday Experienced in Turkey? \\ Burçe AKCAN* \\ Merve GENÇYÜREK ERDOĞAN** \\ Süleyman KARAÇOR ${ }^{* * *}$
}

$\ddot{O} Z$

Tüketimin özel günler vasıtasıyla teşvik edildiği günümüz toplumlarında, alışveriş planlama gerektiren ve ciddiye alınmasl gereken bir aktivite haline gelmiştir. Küresel pazarda firmalar kimi zaman 'geleneksel' kimi zaman da "yeni”" satış ve pazarlama stratejileri ile bu sürecin baş aktörleri olarak görülmektedir. Günler önce başlayan reklam faaliyetleri ile tüketicilerin markalı kampanyalara dahil olduğu, indirim kuponları ve kodlarl topladıkları, alışverişlerini planladıkları, bir gece önceden mă̆azaların önünde sıraya girerek bekledikleri, kısıtlı zamanda adeta yarışarak bir tüketme hazzı yaşadıkları gözlemlenmektedir. Amerika'da Şükran Günü'nden sonraki ilk Cuma yapılan, tüketimin en üst düzeye ulaştı̆̆ "Kara Cuma" tüketim günleri içinde en yaygın olanı ve en bilinenidir. Her sektörden firmanın çeşitli indirim oranlarlyla yer aldı̆̆ bu günde, mutlu tüketici profili modern insanın 'daha fazlasına sahip olma' arzusunun pekiştirilmesi ile mümkün olmaktadır. "Kara Cuma” zamanla Amerika sınırlarını aşarak, adeta küresel bir gelenek haline gelmiştir. Son yıllarda Türkiye'de de yaygınlaşan "Kara Cuma” geleneği, Müslümanlar için Cuma gününün kutsal kabul edilmesi nedeniyle küresel pazardaki söyleminin yerele uyarlanmasını gerektirmiş ve deneyimlenme biçimi bakımından Batıdaki örneklerinden farklılaşmıştır. "Kara Cuma” yerine; "Şahane Cuma”, "Muhteşem Cuma”, "Efsane Cuma”" gibi adlandırmalar markaların bu döneme özel kendileri için seçtikleri söylemlerdir. Adeta bir festival havasında geçen indirim günleri, Bankalararası Kart Merkezi (BKM)'nin rekor düzeye ulaşan verileri ile de resmiyet kazanmıştır. Araştırmanın problemine kaynaklık eden soru; tüketimi teşvik eden günlerden biri olan "Kara Cuma” indirimleri, adlandırma biçimi nedeniyle tüketicilerin alışveriş harcamalarına etki etmekte midir? Araştırmanın amacı; globalden (küreselden) glokale (yerele) bu süreçte "Kara Cuma” adlandırmasına yönelik tüketici tutumunun nasıl olduğu, "Kara Cuma"ya yönelik kampanyaların ne düzeyde fark edildiği; tüketicileri "Kara Cuma” da yüksek tüketime yönelten motivasyonların neler olduğu ve son olarak "Kara Cuma”da yapılan harcamaların ne düzeyde dürtüsel olduğu sorularına yanıt aramaktadır. Bu doğrultuda çalışma nicel bir yaklaşım ile tasarlanmış olup, veri toplama tekniği olarak anket çalışmasından faydalanılmıştır.

ANAHTAR KELIMELER

Kara Cuma, Tüketim, Alışveriş, Indirim, Özel Tüketim Günleri

\footnotetext{
* Arş. Gör. Dr., Selçuk Üniversitesi, İletişim Fakültesi, Reklamcıllk, burce@selcuk.edu.tr, ORCID: 0000-0003-0907-8229

** Öğr. Gör. Dr., Ankara Hacı Bayram Veli Üniversitesi PSBMYO, Görsel İ̧̧itsel Teknikler ve Medya Yapımcılığı, mervegencyurek@gmail.com, ORCID: 0000-0002-6913-3974

**** Prof. Dr., Selçuk Üniversitesi, İletişim Fakültesi, Reklamcılık, skaracor@selcuk.edu.tr, ORCID:0000-0002-3146-0232
} 


\begin{abstract}
In today's societies which consumption is encouraged through special days, shopping has become an activity that requires planning and needs to be taken seriously. In the global market, firms are seen as main actors of this process with their both 'traditional' and "new" sales and marketing strategies. With the advertising campaigns that started days ago, it is observed that consumers are taken part in branded campaigns, collect discount coupons and codes, plan their shopping, wait in front of the stores one night in advance and feel the pleasure of consuming by competing in limited time. Consumption reaches its highest level in the US on the first Friday after Thanksgiving and is called "Black Friday". That day is pretty common and known among consumption days. Companies from almost all industries take part in that special day with various discount rates and the happy consumer profile is made possible by reinforcing the "desire to have more" of modern man. Black Friday has become widespread in recent years in Turkey. This requires local adaptation of the discourse in the global market because Friday, which is described as black, is considered sacred for Muslims. In this respect, it differs from the Western examples in terms of the way it is experienced. Instead of Black Friday, names such as "Great Friday", "Fabulous Friday ", etc. are used by cmpanies to be a part of this campaign period. The discount days, almost like a festival, became official with the record data of the Interbank Card Center (BKM). The question that is the source of the research problem; "How do Black Friday discounts reflect consumers' shopping behaviours due to its negative naming?". With this research, it is tried to reveal how the consumers' attitudes towards the term "Black Friday" is; how degree of the campaigns for Black Friday are noticed; and what motivates consumers to high level consumption on Black Friday and finally how degree of shopping behavior is impulsive in that period. Accordingly, the study was designed with a quantitative approach and the questionnaire was used as a data collection technique.
\end{abstract}

KEYWORDS

Black Ftiday, Consumption, Shopping, Discounts, Special Consumption Days

\begin{tabular}{|c|c|c|}
\hline \multicolumn{2}{|r|}{$\begin{array}{c}\text { Makale Geliş Tarihi / Submission Date } \\
11.10 .2019\end{array}$} & $\begin{array}{c}\text { Makale Kabul Tarihi / Date of Acceptance } \\
18.02 .2020\end{array}$ \\
\hline Attf & $\begin{array}{l}\text { Akcan, B., Gençyürek Erdoğan, M. ve } \\
\text { Yüksekokulu Dergisi, } 23 \text { (1), 43-53. }\end{array}$ & Para Cuma. Selçuk Üniversitesi Sosyal Bilimler Meslek \\
\hline
\end{tabular}




\section{GİRIŞ}

Tüketim kavramı toplumların geçmişten günümüze yaşamsal pratiklerinin önemli bir belirleyicisi olarak değerlendirilmiştir. Bocock (2009) tüketimi "insanların kim oldukları ya da kim olmak istedikleri ile ilgili duyarlılıklarını etkileyen ve gittikçe artan bir şekilde arzulara dayanan bir olgu" olarak tanımlamaktadır. Tarihsel perspektifte değerlendirildiğinde özellikle 1980'li yıllar ve sonrasında gelişen kapitalizmin meşrulaşma sürecinde küresel bir boyut kazanan ticari ilişkilerin, tüketim pratiklerine de yansımasıyla küresel boyutta bir tüketim anlayışı kendini göstermiştir. Bireylerin, kitle iletişim araçlarında sergilenen malları ekonomik güçleri yeterli olmasa dahi "sahip olma arzusu" ile elde ettikleri modern tüketim ideolojisi, tüketim ve arzular arasında bir bağ oluşmasına neden olmuştur (Bocock, 2009:13). Tüketim ihtiyaç temelli bir faaliyet olmaktan öte yaşam tarzı, statü gibi göstergeleri işaret eden bir prestij edinim aracı olarak görülmektedir.

Featherstone (2013:155) kültürel anlamda tüketimin bir proje olarak görüldügünü, bireylerin yaşam tarzı çerçevesinde ürünler, giysiler, görünüş ve bedensel özelliklerin tikelliğinde, kendi bireyselliklerini ve üslup anlayışlarını teşhir ettiklerini ifade etmiştir. Günümüz modern endüstri toplumlarında maddi unsurların ön planda olduğu, sosyal ilişkilerin ticari boyut kazandığı ve toplumsal anlamda değer yargıların değişmesine sebep olan bir takım tüketim stratejileri gelişmiştir. Bu stratejiler; aşırı tüketim (her şeyin ikincisini alma gibi), kullan-at mantığında üretim gerçekleştirme, reklamlar aracılığ ile sahip olma arzusu yaratma, modaya uygun mal üretme (kalitesi düşük ancak psikolojik açıdan tatminkâr), moda olmayanı kullanmama, hatta atma ve tüketimi kışkırtıcı kampanyalar olarak sıralanabilir (Kocacık,1998:45).

Geleneksel mecraların yanı sıra yeni medya olarak adlandırılan internet tabanlı dijital dünya, tüketim stratejilerinin benzer mantıkta ancak farklı biçimlerde kendini gösterdikleri bir alan olarak karşımıza çıkmaktadır. Tüketim mallarının yeni mecrası olan internet, zaman ve mekâna dayalı farklılıklardan kaynaklı sorunları ortadan kaldırarak özellikle batının kapitalist toplumları ile diğer toplumlar arasında kurulan bağın yeni adresi olmuştur. Günümüzde bireylerin tüketim nedenleri sıralanırken gereksinimler, kalite ya da beğeni gibi gerekçelere; firsatı kaçırmak istememe, kampanyalara dahil olma ve ihtiyacı olmasa dahi tüketerek tatmin olma gibi gerekçeler de eklenmiştir. "Kara Cuma" bahsi geçen değerlendirmelere örnek teşkil eden kışkırtıcı bir kampanyadır. Çalışma kapsamında iktisadın önerdiği 'homo-economicus' üzerine pazarlama çalışmalarında yeniden düşünülmesi gerektiğinin altı çizilerek dini hassasiyetlerin kapitalist anlayışa entegrasyon süreci "Kara Cuma" özelinde tarihsel bağlamından koparılmadan ele alınmaktadır.

\section{HOMO-ECONOMICUS VE HOMO-CONSUMERICUS}

Ekonominin insan davranışına dair iki temel varsayımı vardır: insanlar rasyoneldir ve çıkarcıdır (Goodwin vd, 2014: 178). Bu yaklaşımdan hareketle "homo-economicus" insan modeli tanımlanmıştır. Ancak yakın dönemde ekonomistler tüketim kararlarının ultra-rasyonel homo-economicus tarafından değil, davranışları rasyonellikten uzak olabilen gerçek insanlar tarafından verildiğini öne sürmektedir (Mankiw, 2003: 519). Dolayısıyla günümüz tüketicisi için satın alma, belli bir ihtiyacın giderilmesi için yapılan takas işleminden ${ }^{1}$ oldukça farklıdır. Bugün, pazarda bir ihtiyacı karşılayacak geniş ihtimaller seti söz konusudur ve tüketiciler ihtiyaçlarını giderme yetisine sahip olan bu setten bir seçim yaparak satın alım gerçekleştirmektedir. Teorik olarak birbirinden farklı noktalara işaret eden istek ve ihtiyaç olguları, günümüz tüketicisinin satın alma edimleri ile muğlak bir yapıya bürünmektedir. Öyle ki, günümüz tüketicisi, sadece yaşamsal ihtiyaçlarını karşılamak için tüketim yapan, tüketmeden önce araştıran, planlayan akılcı ve mantıklı homo-economicus'tan kopmuş (Ryan, 2003: 245), Odabaşı (2009: 2)'nın ifadesiyle sembolik anlamlar ve çeşitli düzeylerdeki ihtiyaçlarına yönelik tüketim gerçekleştiren "homo-tüketimus" a evrilmiştir. Bu evrim süreci neredeyse bütün pazarlama kitaplarında bu şekilde ifade edilse ve kimlerince eleştirilse de homo-economicus kavramsallaştırması kendi içinde tartışmalı bir konumda bulunmaktadır. Akıl ve mantık sahibi özellikleri atfedilen ve bugünün ütopyası olarak gösterilen homo-economicus "faydayı maksimize etmek" amacıyla (Mill, 2018: 65) değerlerinden ve ilkelerinden uzaklaşmış bir profili işaretlemektedir (Çaylak, 2016). Mantıktan uzak bir formülasyonu işaretleyen ve tüketimlerinin çoğunu duygusal gereksinimler ile gerçekleştiren homotüketimus ise, bu süreçte rasyonellikten uzak bir bağlamı işaretleyerek homo-economicustan ayrışmaktadır. Öyle ki, Amerikalı yazar Marya Mannes (aktaran; Goodwin vd., 2014: 182) ak1llı bir insanın duygu yönetimini, mantığını kullanarak yaptığını belirtmektedir. Bu ifade duygulara aşırı güvenmenin irrasyonel davranışlara yol açabileceği anlamına gelmektedir. İdeal rasyonel bireyi tanımlayan homo-economicus'un fayda maksimizasyonunu gerçekleştirirken sosyal yaşamda nerede olduğu ve diğerleri ile nasıl ilişki kurduğu çoğunlukla pazarlama araştırmalarında göz ardı edilmiştir. Ubel (2014) Japonya'da oyun tekniği ile yürütülen

\footnotetext{
${ }^{1}$ En basit şekliyle takas; bir mal veya hizmet için başka bir mal veya hizmetle değişkotuş sürecidir (Mill, 2018: 39).

${ }^{2}$ Orijinal adı homo-consumericus olup Türkçeleştirilmiştir.
} 
bir araştırmada homo-economicus sınıflandırmasında yer alan insanlarda psikopati unsuruna rastlandığını belirtmektedir. Örneğin, oyunlardan birinde katılımcılara para verilerek (oyundaki) ortaklarının hiçbir şey almadığı söylenmiş̧tir. Homo-economicus örüntüsünde davrananlar, ortaklarına hiç para vermeyerek tüm parayı korumuş ve kendi faydalarını maksimize etmiştir. Çalışma neticesinde; katılımcılardan homoeconomicus olanlar ile olmayanlar arasında sahip olunan özellikler bakımından farklılıklar keşfedilmiştir. Homo-economicus kategorisinde yer alanların psikopatik özellikler sergilediği, hayattaki başarının diğer insanların manipülasyonunu gerektirdiğine inandığı, diğer insanlar tarafından takdir edildiklerine dair güçlü bir inanca sahip olduğu ve başkalarının iyiliğini çok az önemsediği görülmüştür. Klasik iktisadın öngördüğü Adam Smith'in görünmez el yaklaşımıyla cisimleşen homo-economicusun kendi faydasını ve çıkarlarını maksimize ederken, ahlaki değerler ve kimi zaman rastlantısal şekilde toplumun genelinin de faydasını teşvik edeceği yaklaşımının (Goodwin vd., 2014: 177) geçersizliği görülmektedir. Bu yaklaşımda yer alan artan bireyciliğin toplumun yararına olacağı inancı, özünde liberal görüşün bir sonucudur (Bayhan, 2011: 223).

Homo-consumericus her ne kadar homo-economicus modelinin devamı gibi görülse de temel farklılık fayda arayışında yer almaktadır. Homo-economicus iktisadi faydasını maksimize etme amacı taşırken, tüketim toplumunun yaygın modeli olan homo-tüketimus duygusal faydaya odaklanmaktadır. Öyle ki, kompülsif satın alma, dürtüsel satın alma gibi tüketim problemleri, tüketim toplumu bireyi olan homo-tüketimus ile özdeşleşmektedir. Tüketim toplumuna evrim süreci şüphesiz bir anda olmamış ve toplumsal, ekonomik alandaki değişim ile dönüşümlerden etkilenmiştir. Kapitalizmin bir ürünü olan tüketim kültürünün aynı zamanda kapitalizmin kültürü olduğu kabul edilen bir gerçekliktir. Bayhan (2011), kapitalizmin sanayi devrimi gibi tüketici devrimi ürettiğini ve tüketiciliğin ortaya çıkışının sadece kurumsal değişimi değil, tutum ve davranış değişimlerini de içerdiğini belirtmiştir. Bu durumu önceden seçkin gruplarla sınırlı olan moda akımlarını takip etmenin yaygınlaşması örneklendirmektedir. Böyle bir sosyal yapıda bireylerin toplum içindeki konumları tükettikleri ile ölçülmekte bu da homo-tüketimusu yaygın insan modeli haline getirmektedir.

\section{TÜKETIM TOPLUMUNA GEÇIŞ VE MUHAFAZAKÂR KESIMMIN KAPITTALİST SİSTEME ENTEGRASYONU}

1929 ekonomik buhranı ve sonrasındaki gelişmeler Batılı ülkelerin ekonomik yönden yapılanmasındaki klasik liberalizmi dönüştürerek, ekonomiye devlet müdahalesini öngören "refah devleti" veya "sosyal devlet" anlayışını ortaya çıkarmıştır. 1970'li yıllarla birlikte klasik liberalizmden farklı olarak liberal düşüncede muhafazakarlığın toplumsal değerlere eklemlenmesi esasına dayanan "yeni sağ" ya da "liberal muhafazakarlık" adıyla yeni bir görünüm meydana getirmiştir. Yeni sağ anlayışı, özünde liberalizmin piyasa ekonomisi ve sınırlı devlet ilkeleri ile muhafazakarlığın toplumsal değerlere vurgu yapan anlayışının bir sentezi olarak görülmüştür. Bu sentez Amerika ve İngiltere'de uygulama karş1lı̆̆ bularak Reaganizm, Thatcherizm gibi adlarla anılırken, Türkiye'de 24 Ocak 1980 kararları liberal ekonomiye geçişin ilk adımları olmuştur. 1983'te iktidara gelen Turgut Özal önderliğinde birçok alanda dönüşüme ortam hazırlanmıştır. Böylelikle yeni sağ politikaların Türkiye'deki uygulaması "Özalizm” adıyla anılmıştır (Şener ve Çolak, 2015: 393-394). Turgut Özal ile ithalat serbestisi gelmiş ve tüketim ürünlerinde bir bolluk yaşanmıştır. 12 Eylül öncesi yokluk, kitlık ve kuyruk ile karakterize tarih, Turgut Özal'ın ekonomik alandaki reformları ile dönüşüme uğramıştır (Erdoğan, 2017: 403). 1970'li yıllardaki yokluk kültürünün 1980'li yıllarla beraber bolluk kültürüne evrilmesi gündelik hayat içerisinde de kendine yer bulmuş ve Bali (2013: 33) bu durumu “zengin olmak özlemi” olarak nitelendirmiştir. 1970’li yılların “yaşamak için tüketim” söylemi 1980’li yıllarla birlikte "tüketim için yaşamak" söylemine dönüşmüştür.

1980'lerde uygulanmaya başlanan ekonomik liberalizm politikaları dini hassasiyete sahip muhafazakâr kesimler tarafından tepki ile karşılanmıştır. Öyle ki Erdem (2011:7), Kur'an İslam'ının hiçbir koşul altında kapitalizm ile uyum sağlamasının mümkün olmadığını belirtmektedir. Ancak zaman içerisinde dindar siyasiler dahi kapitalist sistem ile bütünleşmişlerdir (Demirezen, 2016: 548). Böylelikle muhafazakarlığa dindarlık ekseninde tüketim boyutu eklenmiş ve Turgut Özal'ın 'Zengin bir Müslüman fakir bir Müslümandan daha iyidir" söylemi ile bu durum güçlendirilmiş̧ir. Özal döneminde, muhafazakâr değerlere ve dini hassasiyete sahip sermayeyi kapitalist sisteme dahil etmek adına yapılan en önemli girişimlerden biri; yasal düzenlemeler vasitasıyla İhlas Finans, Anadolu Finans, Kuveyt Türk gibi İslami bankacılık kuruluşlarının hayata geçirilmesidir (Erdoğan, 2017: 402-403). Dini hassasiyete sahip muhafazakâr kesimin ekonomik olarak gelişmesi ve kapitalist sisteme entegrasyonu, Türkiye'nin tüketim toplumuna dönüşmesiyle birleşince muhafazakâr kesim de tüketim toplumuna uyum sağlamaya başlamıştır. Dini değerleriyle tüketim değerlerini bağdaştırmaya çalışan ve eklektik bir melez kültürün çıkmasına imkân veren muhafazakâr kesim, tüketim toplumu değerlerinin de etkisiyle kendine bir hayat tarzı oluşturmaya başlamıştır (Demirezen, 2016: 549-550).

Selçuk Üniversitesi Sosyal Bilimler Meslek Yüksekokulu Dergisi, Yıl: 2020 Cilt: 23 Sayı:1 
Modernizme tepki olarak şekillenen muhafazakarlığın zaman zaman dinsellik vurgusu ile bağımsız bir kanal oluşturmaya çalıştığının altını çizen Yücesoy (2013: 63), sözü edilen siyasal bağımsızlık durumunun iktisadi alandaki liberalizmle uzlaşan muhafazakarlıkta görülmediğini ifade etmektedir. $\mathrm{Bu}$ uzlaşı da liberalizme içkin kültürel kabullerin muhafazakarlıkla aynı potada erimesine sebep olarak muhafazakarlığı, modernleşme sürecinde alternatif bir biçim haline getirmiştir. Bunun derininde Türkiye modernleşmesinin Batı'dakinden farklı olması yer almaktadır. Kılıçbay ve Binark (2002: 496-497) Türkiye modernleşmesinin Batı'dan farklı olarak homojen ve tek kültürlü kimliği pekiştirdiğini, farklı kimlik ve toplumsal hareketleri kamusal alandan uzak tuttuğunu ifade etmiştir. Bu bağlamda 1920'lerin başından 2000'lerin başına kadar askeri subaylar, bürokratlar ve Kemalist aydınları içeren ulus-devlet elitlerinin görünür alanda yer aldığını belirtmektedir. Yaşanan süreç şüphesiz demokratik koşulların göz ardı edilmesi anlamını taşımaktadır ve yazarlar, 1990'ların başından itibaren yerel burjuvazi ile dinin görünür hale geldiğinin, Refah Partisi'nin 1994 yılında belediye seçimleri ile başarı elde etmesi ile de siyasi düzlemde varlığını cisimleştirdiğinin altını çizmektedir. Demirezen (2016: 548), Refah Partisi'nin 1996 yılında iktidara gelmesinin muhafazakâr kesimin ekonomik olarak gelişmesine ivme kazandırdığını ancak 28 Şubat süreci ile kazanımların kesintiye uğradığını belirterek, muhafazakâr kesimin ekonomik ilerleyişinin 2002 yılında muhafazakâr bir parti olan AK Parti'nin iktidara gelmesi ile gerçek anlamda sağlandığı ve hızlandığını belirtmektedir.

Akçaoğlu (2019: 87-105), önceki kuşaklarda görülen kapitalist piyasa sistemine kuşkulu yaklaşımın genç kuşaklarda dönüşüme uğradığına dikkat çekerek bu meseleyi "kusurlu piyasa koşulları içinde şuurlu Müslüman olma" çabası ile açıklamaktadır. Ayrıca muhafazakâr orta sınıfın yeni ekonomik düzende farklılaşma gerekçesinin doğrudan din değil, dinle kurulan ilişki olduğunu belirtmektedir. Dolayısıyla problemin esası inançlar düzeyinde değil uygulamalar ve davranışlar düzeyinde belirginleşmektedir (Pişkin, 2016: 139).

\section{TÜKETIM İÇIN OLUŞTURULAN ÖZEL GÜNLER: KARA CUMA}

Günümüz tüketim toplumunda anneler günü, babalar günü, kadınlar günü, sevgililer günü, öğretmenler günü gibi "özel günlerde hediye amaçlı tüketim yapılması" ve yapılan harcamaların rekor rakamlara ulaşması alış1lık bir durum iken "tüketim için oluşturulan özel günler" bu denli bilindik değildir. Bu çalışma ile son yıllarda bir trend haline gelen ve hızla yaygınlaşan özel tüketim günlerine odaklanılmaktadır. "11.11"; "Kara Cuma", "Cyber Monday", "Mega Mayıs" bu günlere örnek olarak gösterilebilir. Bu günlerin, alışverişin yoğun olduğu anneler günü, sevgililer günü, yılbaşı, bayramlar gibi günlerden farkı; çıkış noktalarında anma veya duygusal anlamlardan ziyade doğrudan satın alma olgusunun bulunması ve salt tüketim odaklı olmasıdır.

Çalışma kapsamında son birkaç yıldır ülkemizde de yaygınlaşan Amerika menşeili "Kara Cuma" ele alınmıştır. "Kara Cuma", hem tüketimin rekor rakamlara ulaştığı hem de hakkında çok sayıda eleştirinin söz konusu olması sebebiyle diğer tüketim günlerinden ayrışmaktadır. Başka bir ifadeyle, bir tarafta "Cuma'nın karası olmaz" argümanı ile bu tüketim gününe eleştiriler yöneltilmekte; diğer taraftan 23 Kasım 2018'e denk gelen "Kara Cuma"da yapılan harcamalar dikkat çekecek düzeyde artmaktadır. Türkiye'de 2018 yılında bahsi geçen günde kredi kartları, banka kartları ve sanal kartlar kullanılarak tek bir günde sadece internet üzerinden 3,4 milyar Türk Lirası harcama ile 2 milyon farklı kartın kullanımı gerçekleştirilmiştir. Yıl bazlı değerlendirildiğinde rekor kıran bu rakamlar, özellikle elektronik eşya sektörü, giyim ve aksesuar ile hava yolları sektöründe yoğunlaşmaktadır. Ayrıca ülke genelinde internetten en fazla alışveriş yapan şehirler yüzde kırkla Iğdır, yüzde otuz dörtle Kırklareli ve yüzde otuz üçle Çanakkale olarak tespit edilmiştir ${ }^{3}$. Böyle ikircikli bir durumda gerçeğin ne olduğu değil, nasıl deneyimlendiği önem arz etmektedir. En çok alışveriş yapılan şehirlere bakıldığında özellikle ülkenin batısında ve doğusunda yer alan iller olduğu dikkate değer görülmektedir. Kışkırtıcı kampanyalardan haberdar olan tüketiciler, "fırsatları kaçırmamak, bu kampanya gününde bulundukları şehrin mevcut imkanları sebebiyle büyük alışveriş merkezlerine gidemeseler dahi internet aracılığıyla indirimden faydalanmak" gibi gerekçelerle sürecin önemli bir parçası olmuşlardır.

Türkiye'de eleştirilerin odağı olan ancak kendi özelinde hem reklam endüstrisi ile tüketicilere sürekli hatırlatılan hem de tüketicileri alışverişe yönlendirilen "Kara Cuma"nın ne olduğu ve nasıl ortaya çıktığına dair farklı tanımlamalar ve teoriler bulunmaktadır. Oxford Lexico Sözlüğü ${ }^{4}$ ne göre "Kara Cuma" adlandırmasının sebebi perakendecilerin siyah renkte olduğu yılın ilk günü olmasıdır. Buradaki mantık teknik olarak bir hesabın alacak tarafı siyah, borç tarafı kırmızı mürekkeple kaydedildiğinden, günlerdir kırmızı olan mali durumun en azından tatil alışverişi sayesinde siyaha dönmesinin sevinçle karşılanmasıdır.

İkinci bir teoriye göre; Kasım ayının dördüncü perşembesi Şükran Günü'ne denk gelmektedir ve 1952 yılından beri tatil alışveriş sezonunun başlangıcı bu gün olmaktadır (Smith ve Raymen, 2014: 677;

\footnotetext{
${ }^{3}$ https://bkm.com.tr/raporlar-ve-yayinlar/donemsel-bilgiler/ (Erişim Tarihi: 05.08.2019)

${ }^{4}$ https://www.lexico.com/en/explore/why-is-day-after-thanksgiving-black-friday (Erişim Tarihi: 09.08.2019)
} 
Chandrasekaran, 2018: 92; Lennon vd., 2018: 71; Thomas ve Peter, 2011). Şükran günü; aile ve arkadaşlar ile bir araya gelerek ilişkilerin pekiştirildiği ve bahşedilen tüm armağanlar için duyulan şükranın ifade edildiği bir gündür. 19. Yüzyılda Abraham Lincoln tarafından tayin edilmiştir. İnsanlar, Şükran Günü'nü takiben yakın zamanda gelecek olan Noel ve Yılbaşı için alışveriş yapmaya başlamaktadırlar ve Şükran Günü'nün ertesi "Kara Cuma" ve "Kara Cuma"nın ertesi de insanların mesaiye döndüğü Pazartesi'yi işaret eden Cyber Monday (Siber Pazartesi) olarak anılmaya başlamıştır. Bu sayede insanlar ofisten çıkma gereksinimi olmadan çevrimiçi olarak alışveriş yapmaya devam etmiştir (Chandrasekaran, 2018: 92). Bu teoriye göre "Kara Cuma", Amerika'da Şükran Günü'nden sonra tatil alışverişi sezonunun geleneksel başlangıç günüdür. Son olarak başka bir teoriye göre; 1932'yi takip eden yıllarda Noel alışverişinin başlama tarihi olan Cuma gününde yaşanan ölümler ve yaralanmalar, aşırı kalabalık ve şehirde yaşanan yoğun trafik sebebiyle ilk kez 1965 yılında bir yerel gazetede "Black Friday" olarak anılmıştır (Thomas ve Peter, 2011: 522).

"Kara Cuma"nın Batı kökenli anlamları dışında madalyonun diğer tarafına bakıldığında Cum'a suresinin 9 , 10 ve 11. ayet tefsirlerine ${ }^{5}$ göre Müslümanlar Cuma vakti alışveriş, eğlence ve ticaretten uzaklaşmalı, namaza ve Allah'a yönelmelidir. Bu bağlamda Cuma'nın kutsal oluşu, dinen ticaretten, alışverişten uzak durmanın öğütlenmesine karşın sözü edilen günün alışveriş yapmayı teşvik etmesi ve "kara" sözcüğü ile nitelenmesi olumsuz çağrışım yaratmaktadır. Bu sebeple İslami hassasiyete sahip tüketiciler tarafından değerlere saldırı olarak değerlendirilerek yeni bir anlam ekseni oluşturulmaktadır. Bu durum bürokrasi düzeyinde de yeniden üretilerek tepkilerin odağı haline gelmiştir. Buna örnek olarak Cumhurbaşkanı Baş Danışmanı ve Gençlik ve Spor Bakanı Yardımcısı Hamza Yerlikaya'nın 24 Kasım 2017'de "Kara Cuma"ya tepkisini gösteren ve bu günü bir operasyon olarak değerlendirdiği tweeti ${ }^{6}$ gösterilebilir. Bu tweet 539 kez retweet edilmiş 1388 beğeni almıştır. Ayrıca 1 Aralık 2017'de Diyanet İşleri Başkanlığı bir hutbe yayınlayarak "Kara Cuma"ya tepki göstermiştir?

Bu süreçte kimi markalar "Black Friday" veya "Kara Cuma" adlandırmasını tercih ederken kimi markalar tepki çekmemek adına alternatif adlandırmalara gitmiştir. Bunlara örnek olarak; Hepsi Burada'nın "Efsane Cuma", Trendyol'un "Efsane Günler", Gittigidiyor'un "Süper Cuma", Amazon'un "Beklenen Cuma", Arçelik'in "Cuma Aşkına”, Media Markt'ın "Şahane Cuma”, Morhipo'nun "Black Sale", Teknosa'nın "Tekno Cuma", Penti'nin "Pink Friday", ePTT AVM'nin "Bereketli Cuma" adlandırmaları gösterilebilir. Vestel ve Başakşehir Store "Hayırlı Cumalar" adlandırmasını tercih ederek İslami hassasiyetlerini göstermişlerdir. Bu sayede hem tüketicinin tepkisinin önüne geçilmeye çalışılmış, hem de tüketimin yoğun olduğu bu günde ticari faydadan mahrum kalmamak mümkün olmuştur. Burada dikkate değer son alternatif kullanım, hedef kitlesi genel olarak muhafazakâr tüketiciler olan "Moda Nisa" markasının herhangi bir adlandırma kullanmadan "Kara Cuma" zaman diliminde kampanya yapması ve bunu "yılın en büyük kampanyası" olarak nitelendirmesidir ${ }^{8}$. Şahin ve Yünaçtı (2018: 401), markaların bu dönemde yaptıkları kampanya ve içerikler ile tüketicinin bilişsel çelişki durumunun ortadan kaldırılmasının amaçlandığı belirtmektedir. Görüldüğü üzere markalar adlandırma düzeyinde "Kara Cuma"ya tepki gösterseler dahi tüketime yönelik talebin yoğunlaştığı bu zaman diliminde ticaretten uzaklaşmamaktadırlar. Bu durum tüketici düzeyinde de görülmekte olup kullanıcılar haber siteleri, imza siteleri, elektronik sözlükler, forum siteleri, sosyal ağ sitelerinde "Kara Cuma"ya yönelik tepkilerini göstermiş ancak tepkileri onları alışveriş davranışından uzaklaştırmamıştır. Yaşanan süreç dinlerin anlam dünyaları ile tüketim toplumundaki anlam dünyasının temel karşıtlıklarının meydana getirdiği bir mücadele ortamını (Pişkin, 2016: 137-138) işaretlemektedir.

Tamamen hedonik bir tüketim alanı olan özel günlerde tüketiciler, çoğunlukla bilinçli olduklarını iddia etseler dahi onları alışverişe ve tüketmeye yönelten şeyin ne olduğunun farkında değildirler. Dholakia (2000'den aktaran Karaca vd., 2018: 420)'nın araştırmasına göre; tüketiciler promosyonlu ürün ile karşılaştı̆̆ında anlık satın alım yaptıklarını ve yapılan indirimin ekonomik olarak kendilerine faydalı olduğunu ifade etmişlerdir. Şüphesiz ki, küresel anlamda rekor harcamaların gerçekleştiği bir gündeki tüketimlerin gerekçesini salt promosyona karşı savunmasız tüketici olarak değerlendirmek yüzeysel kalacaktır. Suba Iyer (2013) araştırmasında "Kara Cuma"da alışverişleri yönlendiren motivasyonları tanımlamış ve sahip olunan motivasyona göre tüketicilere bilinçli nasıl alışveriş yapabileceklerine dair tavsiyelerde bulunmuştur. Buna göre "Kara Cuma"da alışverişe yönlendiren motivasyonlar; zaman baskısı (sınırlı zaman için), kıtlık (az sayıda

\footnotetext{
5 (9) Ey iman edenler! Cuma günü namaz için çağrı yapıldığında Allah’ı anmaya koşun ve alışverişi bırakın. Eğer bilirseniz, bu sizin için çok hayırlıdır. (10) Namaz kılındı mı artık yeryüzüne dağılın ve Allah'ın lutfundan nasip arayın. Allah’ı da daima çok anın ki kurtuluşa eresiniz. (11) Ama onlar bir ticaret veya eğlence gördüklerinde ona yönelip seni ayakta bırakıverdiler. De ki: "Allah'ın nezdinde olan, eğlenceden de ticaretten de üstündür. Allah rızık verenlerin en hayırlısıdır." https://kuran.diyanet.gov.tr/tefsir/Cuma-suresi/5186/9-11-ayet-tefsiri (Erişim Tarihi: 9 Ağustos 2019)

${ }^{6} \mathrm{https}$ ://twitter.com/hamzayerlikaya/status/934022936322768896 (Erişim Tarihi: 9 Ağustos 2019)

${ }^{7}$ https://www.diyanet.gov.tr/tr-TR/Content/PrintDetail/11075 (Erişim Tarihi: 9 Ağustos 2019)

${ }^{8}$ https://pazarlamailetisimi.com/tesettur-markasindan-black-friday-uyarlamasi/ (Erişim Tarihi: 7 Ağustos 2019)
} 
kalan ürünler), toplumsal onay arayışı, rekabet ve benlik (ego) yükseltme ile ritüel olarak tanımlamaktadır. Dolayısıyla "Kara Cuma"da yapılan tüketimler çok boyutlu bir bağlamda gerçekleşmektedir.

\section{ARAŞTIRMANIN YÖNTEMI}

"Kara Cuma", önceki bölümlerde ifade edildiği üzere Türkiye'de Batıdaki benzerlerinden farklı bir bağlamda deneyimlenmektedir. Hem inanç düzleminde bir karşıtlık durumu, hem de küresel tüketim kültürüne eklemlenme söz konusu olmaktadır. Bilişsel çelişki yaratan bu durumun arka planını anlama amacı taşıyan çalışma ile Türkiye'deki tüketicilerin "Kara Cuma" adlandırmasına yönelik tutumlarının ne olduğu, "Kara Cuma"ya yönelik yürütülen kampanyalarının ne düzeyde fark edildiği”, "Kara Cuma"daki alışverişs motivasyonlarının neler olduğu", "Kara Cuma"ya yönelik tutum ile alışveriş yapma davranışı arasında nasıl bir ilişkinin olduğu" ve son olarak "Kara Cuma"da yapılan alışverişlerin ne düzeyde dürtüsel olduğu" araştırılmıştır. Araştırmanın problemine kaynaklık eden soru; tüketimi teşvik eden günlerden biri olan "Kara Cuma" indirimleri, adlandırma biçimi nedeniyle tüketicilerin alışveriş harcamalarına etki etmekte midir? Araştırmanın hipotezleri şöyledir:

Hipotez 1: Katılımcıların "Kara Cuma" adlandırmasına yönelik tutumları ile kampanya döneminde davranışları arasında bir ilişki vardır.

Hipotez 2: "Kara Cuma" adlandırmasına yönelik tutum ile cinsiyet, eğitim durumu, yaş ve yaşam alanı gibi demografik değişkenler arasında anlamlı bir ilişki vardır.

Hipotez 3: Tüketicilerin yaşam alanlarına ilişkin tanımlamaları ile çevrimiçi alışveriş pratikleri arasında ilişki vardır.

$\mathrm{Bu}$ doğrultuda çalışma nicel bir yaklaşımla tasarlanarak, veri toplama aracı olarak anket tekniğinden faydalanılmıştır. Anket, ücretli bir hizmet sağlayıcısı olan ve katılımcılar tarafından güvenilir bağlantı içeriğiyle, ücretsiz anket platformlarından farklı özelliklere sahip "SurveyMonkey" aracılığıyla hazırlanmıştır.

Çalışmanın evrenini Bankalararası Kart Merkezi (BKM), verilerine göre 23 Kasım 2018 Cuma günü Türkiye' de en fazla internetten alışveriş yapan iller olan; Iğdır, Kırklareli ve Çanakkale ${ }^{9}$ oluşturmaktadır. Bahsi geçen iller kapsamında anket çalışması sosyal medya aracılığıyla gerçekleştirilmiştir. Anketin uygulama aşamasında 01.01.2019-01.03.2019 tarihleri arasında Türkiye'de en çok kullanılan sosyal medya platformlarından biri olan Twitter' $\mathrm{da}^{10}$ anket bağlantısını içeren ve konu hakkında özetleyici bilgiye yer verilen tweetler atılmıştır. Çalışmanın amaçları gereği tanımlanan örneklem Iğdır, Çanakkale ve Kırklareli'nden katılımcıları içermektedir. Buna göre nüfus verilerini oransal olarak yansıtması bakımından örneklem büyüklüğü tabakalı örneklem tekniği ile oluşturulmuştur. TÜIK'in adrese dayalı nüfus kayıt verileri çalışma evreninin tanımlanmasında temel alınmış olup buna göre Iğdır nüfusu 197456, Çanakkale nüfusu 540662, Kırklareli nüfusu 360860 olup bu oran korunarak çalışmaya katılan katılımcı sayıları Iğdır'dan 81 (\%17,96), Çanakkale'den 221 (\%49), ve Kırklareli'nden 149 (\%33,04) olmak üzere otomatik olarak sınırlandırılmıştır. ${ }^{11}$

Hazırlanan anket beş farklı bölümden oluşmaktadır. Anketin birinci bölümde katılımcının yaşadığı yer bilgisini içeren ilk soru ${ }^{12}$ ve "Kara Cuma'nın ne olduğunu biliyor musunuz?" ifadesini içeren ikinci soru eleyici mahiyette oluşturularak, örneklem grubuna sadece Iğdır, Kırklareli ve Çanakkale'de yaşayan ve "Kara Cuma"nın ne olduğunu bilen katılımcıların dahil olması sağlanmıştır. Bu bölümün devamında katılımcılara "Kara Cuma Motivasyon Ölçeği” sunulmuştur. Oluşturulan ölçeğin güvenilirliği 451 katılımcı ile test edilmiştir ve ölçek yüksek oranda güvenilir bulunmuştur $(n=8 \quad \alpha=.82)$. 4 boyutlu motivasyon ölçeğinin zaman kısıtı boyutu; "O an ihtiyacım olmasa bile gelecekte o fiyata bulamayacağımı düşündügüm ürün/hizmetleri satın alırım" ve "Sinırlı zaman için sunulan teklifleri yakalamak isterim" maddeleri ile ölçülmektedir. Sinırlı kaynaklar boyutu "Kara Cuma döneminde satılan indirimli ürünlerin tükenmesinden endişe duyarım" ve "Sınırlı sayıda sunulan ürünleri satın almak isterim" maddeleri ile ölçülürken, toplumsal ilişkiler boyutu "Çevremdekilerle Kara Cuma döneminde yaptığımız alışveriş hakkında konuşuruz" ve "Kara Cuma döneminde alı̧veriş yapmamak toplumsal bir gerekliliği yerine getirmemek gibidir" maddeleri ile ölçülmüştür. Son olarak benlik (Ego) yükseltme boyutu "Iyi bir teklifi herkesten önce yakalamak isterim” ve "Bir ürünü herkesten önce çok daha uygun fiyata almak iyi hissettirir" maddeleri ile ölçülmektedir. Anket formunun üçüncü bölümü Kara Cuma'da yapılan tüketimin dürtüselliğini ölçmeye yönelik olarak hazırlanmıştır. Bu konunun önemli olduğu düşünülmektedir çünkü çoğunlukla indirim ve promosyon karşısında dirençsiz bir noktaya konumlandırılan tüketicinin, rasyonellikten uzak bir yaklaşımla tüketim

\footnotetext{
${ }^{9}$ BKM, https://bkm.com.tr/raporlar-ve-yayinlar/donemsel-bilgiler/ Erişim Tarihi: 04.04.2019

${ }^{10}$ We Are Social ve Hootsuit tarafından oluşturulan "Digital 2019 in Turkey" istatistiğine göre dokuz milyon aktif kullanıcı sayısı ile Twitter, Türkiye' de en çok kullanılan üçüncü sosyal medya uygulamasıdır. https://digitalreport.wearesocial.com Erișim Tarihi: 02.04.2019

${ }^{11}$ https://biruni.tuik.gov.tr/medas/?kn=95\&locale=tr (Erişim Tarihi: 20 Ağustos 2019)

${ }_{12} \mathrm{Bu}$ soru verilerin analize hazırlanması aşamasında ankete katılan katılımcıların IP bilgilerinin ait olduğu lokasyon ile karşılaştırılması ile doğrulanmıştır.
} 
yaptığ1 öngörülmektedir. Bu bölümde "Kara Cuma"da yapılan harcamaların dürtüsellik durumu oluşturulan ölçüm aracı $(n=3 \alpha=.95)$ ile değerlendirilmiş ve ölçme aracı çok yüksek düzeyde güvenilir bulunmuştur. Uygulanan faktör analizi ile 3 maddenin tamamının tek bir faktör altında toplandığı, yani aynı faktörü ölçtüğü ve toplam varyansın \%87'sini açıkladığı görülmüştür. Bu bölümde yer alan maddeler: "Kara Cuma'da planladı̆̆ımdan fazlasını harcadım”; "Kara Cuma'da satın almak istediğim ürün tükendiğinden aslında ihtiyacım olmayan bir ürünü satın aldım”; "Kara Cuma'da satın aldı̆̆ım bir ya da daha fazla şeyden dolayı pişmanlık duydum" ifadelerini içeren maddelerdir. Dördüncü bölüm katılımcıların "Kara Cuma" adlandırmasına yönelik tutumlarını ifade edebilecekleri tek bir sorudan oluşmaktadır. Son olarak da beşinci bölüm; cinsiyet, yaş, eğitim durumu ve yaşam alanları (il merkezi, ilçe, köy vb.) gibi demografik bilgilerin edinimini sağlayan bir içerik ile sunulmuştur.

\section{BULGULAR}

Verilerin analize hazır hale getirilmesinde eleyici bir soru olan "Kara Cuma'nın ne olduğunu biliyor musunuz?" sorusu katılımcıların yüzde $92(\mathrm{n}=415)$ 'si tarafından evet olarak yanıtlanmıştır. Böylelikle katılımcıların anket sürecine dahil olmaları sağlanmıştır. Düzenlenen ankette katılımcıların demografik bilgileri, yaş, cinsiyet ve yaşam alanı düzeylerinde ölçülmüştür. Katılımcıların yüzde 52,6 (n=226)'sı kadın, yüzde 47,4 (n=204)'ü erkektir. Eğitim düzeyi okuryazar $(n=5, \% 1,2)$, ilköğretim $(n=27, \% 6,7)$, lise $(n=71$; $\% 17,6)$, ön lisans-lisansüstü $(n=232, \% 57,4)$, ve lisansüstü $(n=69, \% 17,1)$ olmak üzere 5 düzeyde ele alınmıştır. Yaşam alanı sorusuna gelen yanıtlar incelendiğinde il merkezi $(n=271, \% 67,1)$, ilçe $(n=88, \% 21,8)$, kasaba $(n=24, \% 5,9)$ ve köy $(n=21, \% 5,2)$ olmak üzere ölçüm yapılan 4 düzeyden de katılımc1 olduğu görülmektedir. Yaş sorusu açık uçlu şekilde sorulmuş olup $(n=404, \bar{x}=31,93 ; \sigma=10,41)$ en genç katılımcı 18, en yaşlı katılımcı 68 yaşındadır.

"Kara Cuma" nın ne olduğunu bilerek çevrimiçi ankete devam eden Iğdır, Kırklareli ve Çanakkale illerinden oluşan örneklem grubunda yer alan katılımcıların yüzde 81,8 (n=369)'i "Kara Cuma" ya da "Black Friday" e ilişkin reklam kampanyalarının dikkatlerini çektiğini beyan etmiştir. Bu durum günümüzde hızla artan dijital reklam yatırımlarının doğru odağını destekler niteliktedir. Öte yandan tüketim için oluşturulan özel günlerin yaygınlaştırılması ve tüketim toplumunun yaygın kültürü içerisinde yer edinmesinde reklamın rol ve önemine vurgu yapmaktadır.

Katılımcıların yüzde 93,3 (n=406)'ü son iki yılda "Kara Cuma"da alışveriş yaptığını ifade etmiştir. Bu rakam "Kara Cuma"da tüketim olgusunun oldukça yüksek bir yaygınlıkla deneyimlendiğini göstermektedir. Araştırmanın örneklemine dahil olan illerin çevrimiçi en çok harcamanın yapıldığı iller olması, ayrıca çalışmanın internet üzerinden yürütülmesi sebebiyle katılımcıların hali hazırda internet kullanıcılarından oluşması, örneklem grubunun internetten alışveriş yapma pratiğinin yüksek olduğuna işaret etmektedir.

Çalışmanın en önemli noktalarından biri, katılımcıların "Kara Cuma" adlandırmasına yönelik tutumları ve bu tutumun alışveriş durumuna yansımasıdır. Adlandırmaya yönelik tutumları olumsuz, nötr, olumlu olmak üzere üç düzeyde ölçümlenmiştir. Araştırmanın ilk hipotezinde kaynaklık eden bu ölçüme göre olumsuz bir tutuma sahip ( $\mathrm{n}=201, \% 46)$ ancak son iki yılda "Kara Cuma"da harcama yapan $(\mathrm{n}=406, \% 93,3)$ katılımcılar en yaygın katılımcı $(\mathrm{n}=191, \% 44)$ profilini işaretlemektedir. Buna karşın adlandırmaya yönelik yine olumsuz bir tutuma sahip $(n=201, \% 46)$ ve son iki yılda "Kara Cuma"da harcama yapmayarak $(n=29 ; \% 6,7)$ tutum ile davranışları uyumlu davranan katılımcı $(\mathrm{n}=10 ; \% 2,31)$ profili oldukça küçük bir grubu içermektedir. Bu veri son derece çarpıcıdır zira "Kara Cuma"ya yönelik en yaygın eğilim adlandırmaya tepkili olsa dahi tüketim ediminden uzaklaşmayan tüketiciler olmaktadır.

"Kara Cuma" adlandırmasına yönelik tutum ile cinsiyet $(p=.362>.005)$, eğitim durumu $(p=.496>.005)$, yaş $(\mathrm{p}=.585)$ ve yaşam alanı $(\mathrm{p}=.303)$ arasında istatistiksel açıdan anlamlı bir ilişki bulunamamıştır. Bu sonuca göre araştırmanın ikinci hipotezi reddedilmiştir. Çelişkili tüketim davranışı biçiminde gözlenen ve tüketicileri "Kara Cuma"da alışverişe yönlendiren motivasyonların araştırılması için geliştirilen ölçeğin verilerine göre "Kara Cuma"da alışverişe dair 4 alt motivasyon olduğu ve her birinin yüksek ortalamalar ile deneyimlendiği saptanmıştır. Bu motivasyonlara ilişkin faktör ortalamaları zaman kısıtı $(\overline{\mathrm{x}}=3,79 ; \sigma=.90)$, sinırlı kaynaklar $(\overline{\mathrm{x}}=3,74 ; \sigma=.86)$, toplumsal ilişkiler $(\overline{\mathrm{x}}=3,6 ; \sigma=.91)$ ve benlik yükseltme $(\overline{\mathrm{x}}=4,21 ; \sigma=.93) \mathrm{dir}^{13}$. En yaygın motivasyon benlik yükseltme olarak görülmüş olup bu bölümde yer alan ifadeler homo-economicus tanımlamasında yer alan rekabetçi, faydacı ve kendi faydasını maksimize etme amacı boyutları ile karşılanmaktadır. Bu dönem alışverişlerinde, katılımcıların en fazla faydacı bir anlayış ile hareket ettiği açık şekilde görülmektedir. İkinci sırada yer alan zaman kısıtı motivasyonu ise pazarlama literatüründe yer alan kısa zaman içinde sunulan teklif ve promosyonlar karşısında tüketicinin dirençsiz olduğunu durumunu

\footnotetext{
${ }^{13}$ Motivasyonlar 1 en düşük 5 en yüksek olacak şekilde ölçülmüştür.
} 
doğrulamaktadır. Bu durum tüketimlerin dürtüselliğini ölçen 3 maddenin ortalamasının 3,98 olması ile doğrulanmış olup bu değer ortalamanın üstünde tepe değere yakın bir yere konumlanmaktadır. En yüksek ortalamaya sahip ifade "Kara Cuma"da planladığımdan fazlasını harcadım" ( $\bar{x}=4,32)$ ifadesi olmaktadır. Dürtüsellik ile sahip olunan motivasyonların karşılaştırıldığı korelasyon analizine göre kısıtlı zaman ( $\mathrm{r}=.298$, $\mathrm{p}=.000<.001)$, sınırlı kaynaklar $(\mathrm{r}=.560, \mathrm{p}=.000<.001)$, toplumsal ilişkiler $(\mathrm{r}=323, \mathrm{p}=.000<.001)$ ve benlik yükseltme $(\mathrm{r}=.453, \mathrm{p}=.000<.001)$ arasında istatistiksel açıdan anlamlı bir ilişki olduğu saptanmıştır. Buna göre "Kara Cuma"da yapılan alışverişlerde sahip olunan her 4 motivasyon da dürtüsel alışverişi yordamaktadır. Dürtüsellik ile en güçlü ilişki sınırlı kaynaklar ve benlik yükseltme motivasyonlarında görülmektedir.

Dürtüsellik boyutu ile yaşam alanı arasında $(\mathrm{r}=-.236, \mathrm{p}=000<.001)$ ters yönde istatistiksel açıdan anlamlı bir ilişki bulunmuştur. Böylelikle çalışmanın üçüncü hipotezi de kabul edilmiştir. İl merkezinden köye doğru gittikçe dürtüsellik artmaktadır. Bu veri, yaşam alanının fiziksel imkanlarının çevrimiçi alışverişe yönlendirici işlevine dair önemli bir ipucu sağlamaktadır.

Dürtüsel alışveriş ile yaş arasında $(\mathrm{r}=.016, \mathrm{p}=.016>.005)$ istatistiksel açıdan anlamlı bir ilişki bulunmazken, eğitim durumu ile $(\mathrm{r}=-.211, \mathrm{p}=.000<.001)$ ters yönde anlamlı bir ilişki saptanmıştır. Buna göre eğitim durumu arttıkça alışverişlerin dürtüsel olma eğilimi azalmaktadır.

\section{SONUÇ}

Tüketimin, satın alma veya harcamadan çok daha karmaşık süreçlerden oluştuğu hususunda şüphe bulunmamaktadır. Bugün, tüketici araştırmalarının geleneksel ve dijital tekniklerine, fizyolojik tepkilerin ölçüldüğg̈ nörolojik teknikler de eklenmiştir. Bunun nedeni bugünün tüketicisinin ekonomi biliminin varsaydığı rasyonel ve tutarlı profilden oldukça farklı oluşu ve buna bağlı olarak pek çok tüketim kararının, tüketim kararını veren kişi tarafindan dahi açıklanamıyor oluşudur. Günümüzde tüketim, ihtiyaçların giderilmesi için yapılan satın alımlar kavramsallaştırmasını çoktan aşmıştır çünkü artık tüketim kavramı, ürün ve hizmetlerin yanında sembolik anlamların da tüketimini içermektedir. Tüketilen her bir nesne bireyi tüketim dünyasının anlam evreninde bir noktaya konumlandırmakta ve bireyler sahip oldukları konumlarını üretimlerinden değil tüketimlerinden elde etmektedirler. Böyle bir bağlamda ne tüketildiği kadar ne tüketilmediği de önemli olmaktadır. "Kara Cuma" tam da böyle bir güne işaret etmektedir. Batı'da Şükran Günü ertesi, Noel alışverişinin başlangıç günü ve tatil alışverişi sezonunun başlangıcı olarak büyük indirimlerin olduğu, harcamaların rekor rakamlara ulaştığ 1 , tüketicilerin merakla beklediği özellikle kampanyaları yakalamak için çaba gerektiren bir gün olarak yaygın şekilde tüketicilerin tüketim pratiğinde yer almaktadır. Buna karşın, Türkiye'de son birkaç yılda yaygınlaşmaya başlayan "Kara Cuma" bilhassa muhafazakâr kesim tarafından tepki ile karşılanmaktadır. Söz konusu tepki markaları dikkatli davranmaya mecbur bırakmaktadır çünkü markalar, hem tüketimin devasa rakamlara ulaştığı bu günden pay almak istemekte, hem de tepki çekmekten imtina etmektedir. Bu durum karşısında markalar, "Kara Cuma"ya alternatif adlandırmalar kullanmak yönünde strateji geliştirmişlerdir. "Kara Cuma"nın Türkiye özelinde deneyimlenme biçimine bakıldığında yukarıda yer alan argümanlar ile çelişkili bir tablo karşımıza çıkmakta ve bu tablo çalışmanın hareket noktasını oluşturmaktadır.

Bankalararası Kart Merkezi (BKM)'nin verilerine göre Türkiye'de "Kara Cuma"nın denk geldiği gün olan 23 Kasım 2018'de tüketim rekor rakamlara ulaşmıştır. En fazla harcamanın yapıldığı iller; Iğdır, Çanakkale ve Kırklareli olarak belirtilmiştir. Bahsi geçen illerden hiçbiri büyükşehir değildir. Dolayısıyla bu durum fiziksel alışveriş imkanları sınırlı olan tüketicilerin, alışveriş pratiklerini çevrimiçi bağlamda sürdürmeye yönlendirdiği değerlendirmesi ile açıklanabilir. Kolay ulaşılabilme imkanı, tüketici açısından önemli bir motivasyondur. Nitekim kampanya dönemlerinde alışveriş merkezine gidebilme ihtimali olan tüketici ile süreci sadece çevrimiçi platformlarda takip etme imkanı olan tüketicinin alışveriş pratiklerini bu sonucu açıklamaktadır. Ayrıca bu durum, çevrimiçi alışverişin geleneksel alışverişin ikamesi haline geldiğini, fiziksel olarak alışveriş imkanlarının kısıtlı olduğu yerlerde çevrimiçi mağazacılığın niş pazar olarak değerlendirilebileceği iç görüsünü sunmaktadır.

Araştırma kapsamında katılımcıların büyük bir çoğunluğu çalışmaya kaynaklık eden "Kara Cuma" döneminde reklam kampanyalarının dikkatlerini çektiğini beyan etmiştir. Dijital reklam pazarı, hedef kitle odaklı içerikleri ile kullanıcılarına "özel" kampanyalar yaratarak, aslında var olanın "kişiye özel" sunumunu kolaylaştırmaktadır. İnternet ortamında bırakılan dijital izler en çok da bahsi geçen kampanya günlerinde işe yaramaktadır. Daha önce herhangi bir arama motoru aracılığıyla ürün ya da hizmet arayan kullanıcı, özel günlerde kampanyalı içeriklerin hedefini oluşturmaktadır. Dijital platformlarda onlarca farklı biçimde sunulan reklam iletileri, kullanıcıların çoğunlukla "maruz kalarak" görmesi sağlanacak şekilde tasarlanmaktadır. 
Dolayısıyla internet kullanıcısı örneklem grubunun büyük oranda kampanyalardan haberdar olması tespitleri doğrulamaktadır.

Araştırmanın önemli olduğu düşünülen noktalarından biri; katılımcıların "Kara Cuma" adlandırmasına yönelik tutumları ile kampanya dönemine denk gelen bu günlerde alışveriş yapma özelinde sergiledikleri davranışların birbiri ile uyumlu olmamasıdır. Çalışmanın problemine de kaynaklık eden bu durumun neticesinde tüketicilerin "Kara Cuma" adlandırmasına olumsuz bir tutum içinde olmakla birlikte, bahsi geçen dönemde tüketim eğilimi göstermekten çekinmedikleri görülmektedir. Tutum ve davranış arasındaki çelişkinin açık bir şekilde gözlendiği tüketici profilinin iç dinamikleri, ilerleyen zamanlardaki çalışmalar için araştırmaya değer görülmektedir. Batı kökenli bir çalışmanın bulgularından hareketle geliştirilen ölçeğin "Kara Cuma"ya yönelik tepkili olan tüketiciler için de geçerli olması, bir başka dikkate değer durum olarak değerlendirilmektedir. 


\section{KAYNAKÇA}

Akçaoğlu, A. (2019) Zarif ve Dinen Makbul, İstanbul: İletişim

Bali, Rıfat N. (2013) Tarzı-1 Hayattan Life Style'a: Yeni Seçkinler, Yeni Mekanlar, Yeni Yaşamlar. İstanbul: İletişim

Bayhan, V. (2011) Tüketim Toplumunda Bireyin Ontolojik Mottosu: Tüketiyorum Öyleyse Varım. Journal of Economy Culture and Society 43(1) 221-248

Bocock, R. (1993) Tüketim, Ankara: Dost

Chandrasekaran, S. (2018) Black Friday: What is it?. Alive. Nisan-2018, 92-95

Çaylak, A. (2016) Neo-Liberalizm, Türkiye ve Müslümanlar, Nida Dergisi. Mart-Nisan 2016 (1)

Demirezen, İsmail, (2016) Türkiye'de Muhafazakar Kesimin Değişen Hayat Tarzı, Hitit Üniversitesi Sosyal Bilimler Enstitüsü Dergisi 9 (2), 547-559

Erdem, E. (2011) Abdestli Kapitalizm. İstanbul: Ozan

Erdoğan, S. (2017) Türkiye'de Yeni Sağcı Ekonomiye Geçiş Uygulamaları ve Turgut Özal. Kastamonu Üniversitesi İktisadi ve İdari Bilimler Dergisi 18 (1), 398-407

Featherstone, M. (2013) Postmodernizm ve Tüketim Kültürü. İstanbul: Ayrıntı

Goodwin, N., Jonathan, M. H., Nelson, J. A., Roach, B., \& Torras, M. (2014) Principles of Economics in Context, Londra: Routledge

Iyer, S. (2013) Psychology of Black Friday: Motivation behind the pursuit of deals, erişim tarihi 09.09.2019, https://www.fivecentnickel.com/psychology-of-black-friday-motivation-behind-the-pursuit-of-deals/

Karaca, Ş., Özbakır Umut, M., \& Yemez, İ. (2018) Özel Gün İndirimlerinin Tüketicilerin Satın Alma Davranışları Üzerindeki Etkisinin İncelenmesi. Iğdır Üniversitesi Sosyal Bilimler Dergisi 16, 413-436

Kılıçbay, B. ve Binark, M. (2002) Consumer Culture, Islam and the Politics of Lifestyle: Fashion for Veiling in Contemporary Turkey, European Journal of Communication 17(4), 495-511

Kocacık, F. (1998) Tüketim Eğilimleri ve Sorunları. Sivas: Cumhuriyet Üniversitesi Yayınları.

Lennon, S. J., Kim, M., Lee, J., \& Johnson, K. K. P.., (2018) Consumer Emotions on Black Friday: Antecedents and Consequence, Journal of Research for Consumer 32 (1), 70-109.

Mankiw, N. G., (2003) Macroeconomics. New York: Worth Publishers,

Mill, A. (2018) Ekonomi 101 (Çeviren: Nurdan Soysal). İstanbul: Say

Odabaşı, Y. (2009) Tüketim Kültürü: Yetinen Toplumdan Tüketen Topluma. İstanbul: Sistem

Pişkin, M. (2016) Tüketim Toplumu'nda Din ve Dini Değerler: Lüks Hac ve Umre Örnek Olay1, İnsan ve Toplum. 6(2), 131-149.

Ryan, F. X. (2003) Values as Consequences of Transaction: Commentary on Reconciling Homo Economicus and John Dewey's Ethics. Journal of Economic Methodology 10(2). 245-257.

Smith, O. \& Raymen, T. (2017) Shopping with violence: Black Friday sales in the British context, Journal of Consumer Culture 17(3) 677-694

Şahin, E. \& Yünaçtı, M. (2018) Küresel Tüketim Ritüeli “Kara Cuma”ya (Black Friday) Tüketici Tepkileri ve Çelişkili Satın Alma Davranışı, International Journal of Social Science 71. 387-404

Şener, B. \& Çolak, Ç. D. (2015) “Türkiye'de Yeni Sağ’ın Kamu Yönetimi Anlayışı: Turgut Özal ve ANAP”. Akademik Sosyal Araştırmalar Dergisi 18(3), 393-417

Ubel, P. (2014) "Is Homo Economicus A Psychopath?”, erişim tarihi 20.07.2019, https://www.forbes.com/sites/peterubel/2014/12/15/is-homo-economicus-a-psychopath/\#17c6f7491604

Yücesoy, S. (2013) Türkiye'de Muhafazakarlığın Gündelik Yaşam Estetiği. İnsanbilim Dergisi 1(2), 62-80. 